
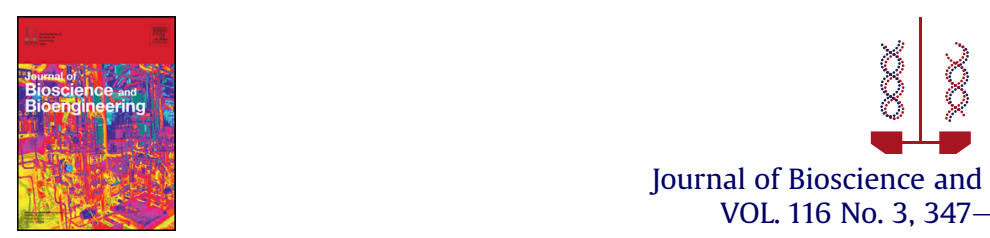

Journal of Bioscience and Bioengineering

VOL. 116 No. 3, 347-356, 2013

ELSEVIER

www.elsevier.com/locate/jbiosc

\title{
Effect of the natural winemaking process applied at industrial level on the microbiological and chemical characteristics of wine
}

\author{
Ciro Sannino, Nicola Francesca, Onofrio Corona, Luca Settanni, Margherita Cruciata, and \\ Giancarlo Moschetti*
}

Department of Agricultural and Forestry Science, University of Palermo, Viale delle Scienze 4, 90128 Palermo, Italy

Received 1 January 2013; accepted 6 March 2013

Available online 21 April 2013

\begin{abstract}
The composition of yeast and lactic acid bacteria (LAB) communities and the chemical evolution of the large-scale commercial vinification of Catarratto IGT Sicilia, carried out under the biological regime, was followed from grape harvest until bottling. Simultaneously to the maximum growth of yeasts, LAB counts reached high level of concentration $\left(6-7 \log \mathrm{CFU} \mathrm{mL} \mathrm{mL}^{-1}\right)$ during the first steps of the alcoholic fermentation. Yeast identification was determined applying different molecular methods. The highest species biodiversity was observed on grape and must samples taken soon after pressing. Saccharomyces cerevisiae was detected at dominant concentrations during the entire winemaking process. LAB cultures were grouped and identified by a combined phenotypic and genotypic approach. Leuconostoc mesenteroides, Lactobacillus hilgardii and Lactobacillus plantarum species were identified; the last was the main LAB recognized during vinification. The winemaking process was also chemically monitored. The alcoholic content was approximately $12.67 \%$ $\left(\mathrm{v} \mathrm{v}^{-1}\right)$ at bottling; $\mathrm{pH}$, volatile acidity and total acidity showed a moderate increase during vinification. Tartaric, citric and malic acids decreased until bottling, while lactic acid showed a rapid increase at the end of maceration and bottling. Trans-caffeil tartaric acid was the most abundant phenolic compound and volatile organic compounds (VOC) were mainly represented by isoamylic alcohol, isobutanol, ethyl acetate and octanoic acid.
\end{abstract}

( 2013 , The Society for Biotechnology, Japan. All rights reserved.

[Key words: Lactic acid bacteria; Yeasts; Lactobacillus plantarum; Saccharomyces cerevisiae; Chemical analysis; Spontaneous fermentation; Catarratto grapevine; Sicily; Natural wine]

In the last years, the request for quality wines greatly increased and this phenomenon is still on the increase. Wine is probably one of the main fermented beverages for which the recognition of the territoriality is fundamental for its appreciation. The term terroir, defined as an ecosystem in which the grapevine interacts with the environmental factors (soil and climate) affecting the quality and typicality of the wine produced in a particular location (1), refers to a concept basic during tasting. Several economic and social factors, such as international competition within the wine market and consumer demands for wines with innovative styles, are providing new challenges in winemaking $(2,3)$. In this contest, numerous wine producers are convinced that the premium wine quality is made by traditional methods based on spontaneous fermentation (SF) $(4,5)$ that could yield wines of unique and innovative characters that are particularly appreciated by specialized consumers. To this purpose, a new style of natural winemaking is gaining importance, since the resulting wines are obtained thanks to the action of spontaneous autochthonous agents and the use of chemical additives is not allowed (6).

The SF during winemaking represents the oldest process for wine production. At this proposal, the yeast species present on the

\footnotetext{
* Corresponding author. Tel.: +39 091 23896050; fax: +39 0916515531

E-mail address: giancarlo.moschetti@unipa.it (G. Moschetti).
}

grape surface are undoubtedly defining for the transformation of must into wine, but a relevant role may be played by the transformation environment (6). The complexity of wines obtained with this technology is directly correlated with the nature of the process, initiated and completed by the combined action and/or succession of different species of yeasts (7). Several studies compared wines obtained by SF with those produced using selected yeasts, showing substantial differences in chemical compound composition (8), especially regarding the aromatic complexity and fullness of palate structure detected at higher levels in SF wines (9), as well as in yeast species composition.

The autochthonous microorganisms, in particular yeasts, strongly contribute to the expression of varietal characters $(10,11)$. On the other hand, commercial starter cultures, mainly belonging to the species Saccharomyces cerevisiae drive the alcoholic fermentation and produce wines with wanted characteristics (12), but their employment in winemaking is quite controversial, because of their massive prevalence, after a few days of fermentation, over the native microflora (13). As a consequence, wine peculiarities, such as the complexity of aroma, may be lost. For this reason, besides autochthonous $S$. cerevisiae, non-Saccharomyces species are being object of oenological investigation (14).

Another important factor is represented by the dynamics of succession of the different strains within a given species. Regarding $S$. cerevisiae, the action of different strains provide a better aroma 
complex and individuality to SF wines than commercial yeasts (15). The results of SF do not depend exclusively on yeasts, since lactic acid bacteria (LAB) also play a relevant role during winemaking (16).

Chemical additives are used in foods to combat specific unwanted spoilage and pathogenic microorganisms that are defining for the shelf-life and safety of consumers, respectively. In case of wine, thanks to the ethanol content, low $\mathrm{pH}$ and phenols, the use of chemical compounds does not represent a necessary condition to assure its stability and safety, although, in large-scale productions their employment avoid large economic losses. However, natural wines, produced without oenological additives, are generally carried out in small wineries where the control of grape healthy in vineyards and a right sanitization of the cellar (6), as well as an optimal management of the process limit the risk of alterations.

The present study was conducted to monitor the microbiological and chemical characteristics of Catarratto IGT Sicilia wine during large-scale productions performed according to the natural process.

\section{MATERIALS AND METHODS}

Winemaking processes and sampling The natural winemaking was performed in Azienda Agricola Barraco (Marsala, TP, Italy) with white grapes of the cultivar Catarratto during the vintage 2010. The cultivar object of study was cultivated in the Marsala area (western Sicily-southern Italy) in two vineyards: contrada Badessa (37 $\left.51^{\prime} 27.46^{\prime \prime} \mathrm{N} ; 12^{\circ} 32^{\prime} 31.19^{\prime \prime} \mathrm{E}\right)$ and contrada Masi $\left(37^{\circ} 50^{\prime} 50.08^{\prime \prime} \mathrm{N}\right.$; $12^{\circ} 32^{\prime} 01.92^{\prime \prime} \mathrm{E}$ ). Forty quintals of grape (in duplicate) were manually harvested and subjected to stemmer-crushing. Must was then placed in $50 \mathrm{hl}$ stainless steel vats to let the fermentation take place by indigenous yeasts, naturally present on the grape surface and/or in the winery environment. Sulphites were not added.

The fermentation included, in the first $48 \mathrm{~h}$ after crushing, a maceration: the liquid phase was maintained in contact with the solid parts of grape (skin and seeds) at a constant temperature of $17^{\circ} \mathrm{C}$. After maceration, the entire bulk must was pressed through an hydraulic press and the liquid phase was transferred in $25 \mathrm{hL}$ stainless steel tanks. The fermentation continued at a controlled temperature of $20^{\circ} \mathrm{C}$ for other five days according to the sugar consumption. Subsequently, the liquid mass was subjected to an ageing in steel at a controlled temperature of $20^{\circ} \mathrm{C}$.

The samples for microbiological and chemical analyses were collected before crushing (five hundred grape berries), during fermentation, ageing and at bottling.

Microbiological analysis Grape samples were placed into sterile plastic bags containing a washing isotonic peptone solution $\left(10 \mathrm{~g} \mathrm{~L}^{-1}\right.$ Bacto Soytone, $2 \mathrm{~mL} \mathrm{~L}^{-1}$ Tween 80 ) and incubated at $30^{\circ} \mathrm{C}$ for $3 \mathrm{~h}$ to collect the microorganisms hosted on peel surface (16).

Cell suspensions recovered from grapes, must and wine samples were serially diluted in Ringer's solution. Decimal dilutions were spread plated $(0.1 \mathrm{~mL})$ onto Wallerstein laboratory (WL) nutrient agar, supplemented with chloramphenicol ( $\left.0.5 \mathrm{~g} \mathrm{~L}^{-1}\right)$ and biphenyl $\left(1 \mathrm{~g} \mathrm{~L}^{-1}\right)$ to inhibit the growth of bacteria and moulds, respectively, for the counting of total yeasts (TY). Cell suspensions were pour plated ( $1 \mathrm{ml}$ ) into de Man Rogosa Sharpe (MRS) agar, glucose ( $\left.5 \mathrm{~g} \mathrm{~L}^{-1}\right)$-M17 (GM17) agar and medium for Leuconostoc oenos (MLO) agar ( $\mathrm{pH} 4.8$ ) (17) for the counting of rod, coccus and acidophilic LAB, respectively. All media used for LAB growth were supplemented with cycloeximide (170 ppm) and biphenyl $\left(1 \mathrm{~g} \mathrm{~L}^{-1}\right)$ to inhibit the growth of yeasts and moulds, respectively. All media were purchased by Oxoid (Basingstoke, UK) and chemical by Sigma-Aldrich (Milan, Italy). Incubation was at $28 \pm 2{ }^{\circ} \mathrm{C}$ for 48-72 h for all microorganisms except acidophilic LAB incubated for $5 \mathrm{~d}$. The incubation of LAB was under anaerobic conditions. Analyses were carried out in duplicate.

Yeast isolation and identification Five colonies for each morphology detected on each sample were purified onto WL agar, grouped on the basis of morphology and subjected to genetic characterization.

The DNA extraction was performed using the InstaGene Matrix kit (Bio-Rad Laboratories, Hercules, CA, USA) according to the manufacturer's instructions.

In order to perform a first differentiation of yeasts, all selected isolates were analysed by restriction fragment length polymorphism (RFLP) of the region spanning the internal transcribed spacers (ITS1 and ITS2) and the 5.8S rRNA gene. The DNA fragments were amplified with the primer pair ITS1/ITS4 (18) by means of T1 Thermocycler (Biometra, Göttingen, Germany) and subsequently the amplicons were digested with the endonucleases CfoI, HaeIII and Hinfl (MBI Fermentas, St. Leon-Rot, Germany) at $37^{\circ} \mathrm{C}$ for $8 \mathrm{~h}$. The isolates presumptively belonging to the genus Hanseniaspora were further digested with the restriction enzyme DdeI (MBI Fermentas) (18). ITS amplicons as well as their restriction fragments were analysed twice on agarose gel using at first $1.5 \%\left(\mathrm{w} \mathrm{v}^{-1}\right)$ agarose and then $3 \%\left(\mathrm{w} \mathrm{v}^{-1}\right)$ agarose in $1 \times$ TBE ( $89 \mathrm{mmol} \mathrm{L}^{-1}$ Tris-borate, $2 \mathrm{mmol} \mathrm{L}^{-1}$ EDTA pH 8) buffer. Gels were stained with SYBR safe DNA gel stain (Invitrogen, Milan, Italy), visualized by UV transilluminator and acquired by Gel Doc 1000 Video Gel Documentation System (BioRad, Richmond, VA, USA). Standard DNA ladders were $1 \mathrm{~kb}$ Plus DNA Ladde (Invitrogen) and GeneRuler 50 pb DNA Ladder (MBI Fermentas). Five isolates representative of each group were subjected to an additional enzymatic restriction targeting the 26 rRNA gene. After amplification with the primer pair NL1/LR6 the PCR products were digested with the endonucleases Hinfl, MseI and ApaI (MBI Fermentas) (19) and visualized as above described. One isolate per group was further processed by sequencing the D1/D2 region of the 26S rRNA gene to confirm the preliminary identification obtained by RFLP analysis. D1/D2 region was amplified with primers NL1 and NL4 (20). PCR products were visualized as above. DNA sequencing reactions were performed at Primmbiotech S.r.l. (Milan, Italy). The identities of the sequences were determined by BlastN search against the NCBI nonredundant sequence database located at http://www.ncbi.nlm.nih.gov.

Recognition of $\boldsymbol{S}$. cerevisiae isolates The isolates identified as $S$. cerevisiae species were characterized at intra-specific level through two techniques: interdelta analysis with primers delta12 and delta21 (21) and microsatellite multiplex PCR based on the analysis of polymorphic microsatellite loci named SC8132X, YOR267C and SCPTSY7 (22). The PCR products were analysed on agarose gel 2.0\% $\left(\mathrm{w} \mathrm{v}^{-1}\right)$ in $1 \times$ TBE buffer and visualized as above reported.

Three commercial S. cerevisiae strains (Zymaflore VL2, Laffort; Premium Blanc$12 \mathrm{~V}$, Vason; Uvaferm CS2, Lallemand) commonly used in Catarratto IGT Sicilia area were sampled and analysed as above reported as control strains in order to exclude their presence in winemaking.

Isolation and phenotypic grouping of LAB After growth, colonies of various shapes (at least 5 with identical morphology) of gram-positive (Gregersen $\mathrm{KOH}$ method) and catalase negative (determined by transferring fresh colonies from a Petri dish to a glass slide and adding $\mathrm{H}_{2} \mathrm{O}_{2} 5 \%, \mathrm{v} \mathrm{v}^{-1}$ ) bacteria (presumptive $\mathrm{LAB}$ ) were randomly picked from count plates and transferred to the corresponding broth media. The isolates were purified by successive sub-culturing and stored in glycerol at $-80^{\circ} \mathrm{C}$ until further experimentations.

Rod and coccus-shaped LAB cultures were first grouped on the basis of cell disposition, growth at $15^{\circ} \mathrm{C}$ and $45^{\circ} \mathrm{C}$ and $\mathrm{CO}_{2}$ production from glucose. The last test was carried out in the optimal growth media (MRS for rod LAB and M17 for coccus LAB) containing all components except citrate, whose fermentation by certain LAB may determine gas formation. M17 contained glucose in place of lactose. The assay consisted of LAB inoculation into test tubes sealed with $\mathrm{H}_{2} \mathrm{O}$ agar $\left(2 \%, \mathrm{w} \mathrm{v}^{-1}\right)$. The strains negative to the assay were inoculated into test tubes containing the optima growth media prepared with a mixture of pentose carbohydrates (xylose, arabinose and ribose, $8 \mathrm{~g} \mathrm{~L}^{-1}$ each) in place of glucose. Coccus isolates were further subgrouped on the basis of their growth at $\mathrm{pH} 9.6$ and in presence of $6.5 \% \mathrm{NaCl}$.

Genotypic differentiation and identification of LAB DNA extraction was performed as above reported for yeasts. Strain differentiation was performed by random amplification of polymorphic DNA-PCR (RAPD-PCR) analysis in a 25- $\mu \mathrm{l}$ reaction mix using single primers M13 (23). Amplifications were performed by means of T1 Thermocycler (Biometra, Göttingen, Germany) applying the conditions reported by Zapparoli et al. (24). RAPD profile were analysed on agarose gel $1.5 \%$ $\left(\mathrm{w} \mathrm{v}^{-1}\right)$ in $1 \times$ TBE buffer and visualized as above. One representative culture for each cluster were identified by $16 \mathrm{~S}$ rRNA gene sequencing as described by Weisburg et al. (25).

Chemical analysis of conventional parameters The composition of the wines was determined by means of a Winescan (FOSS) calibrated following EEC 2676 standard procedure (26) for $\mathrm{pH}$, total titratable acidity (TTA), volatile acidity, reducing sugars, ethanol, malic acid, lactic acid, citric acid, tartaric acid, promptly assimilable nitrogen (PAN), glycerol and dry extract. Total and free $\mathrm{SO}_{2}$ were measured with the OIV method, while the end point was revealed by potentiometry as reported by (Huerta Diaz-Reganon, M. D., Ph.D. thesis, Alcala de Henares University, Madrid, 1996).

Phenolic components Hydroxycinnamoyl tartaric acids (HCTA) were tested by HPLC $(27,28)$. The standard employed was chlorogenic acid and the concentration of HCTA was expressed as chlorogenic acid equivalents. By processing these data (hypothetical identity of $\varepsilon$ for chlorogenic and caftaric acids at $220 \mathrm{~nm}$ ) and the data from the coefficients determined by injecting free hydroxycinnamic acids and chlorogenic acid, the concentration of caftaric, coutaric and fertaric acid was estimated. 2-S-glutathionyl caftaric acid was evaluated as caftaric acid equivalents.

Volatile organic compounds (VOCs) Free volatiles were determined according to the method outlined by Corona et al. (28). In brief, $25 \mathrm{~mL}$ of wine, charged with 1-heptanol as internal standard $\left(0.25 \mathrm{~mL}\right.$ of $40 \mathrm{mg} \mathrm{L}^{-1}$ hydroalcoholic solution), diluted to $75 \mathrm{~mL}$ with distilled $\mathrm{H}_{2} \mathrm{O}$, were passed through a $1 \mathrm{~g} \mathrm{C}_{18}$ cartridge (Isolute SPE Columns, Uppsala, Sweden, part no. 221-0100-C) previously activated with $3 \mathrm{~mL}$ of methanol followed by $4 \mathrm{~mL}$ of distilled $\mathrm{H}_{2} \mathrm{O}$. After washing with $30 \mathrm{~mL}$ of distilled $\mathrm{H}_{2} \mathrm{O}$, volatiles were recovered by elution with $12 \mathrm{~mL}$ dichloromethane, dehydrated and evaporated to $0.5 \mathrm{~mL}$ prior to injection into the gas chromatograph (PerkinElmer Autosystem XL, Milan, Italy) and GC-MS (Agilent 6890 Series GC system, Agilent 5973 Net Work Mass Selective Detector, Milan, Italy), both equipped with a DB-WAX column (Agilent Technologies, $30 \mathrm{~m}, 0.250 \mathrm{~mm}$ i.d., film thickness $0.25 \mu \mathrm{m}$, part $\mathrm{n}^{\circ} 122-7032$ ). Oven temperatures: $40^{\circ} \mathrm{C}$ for $2 \mathrm{~min}$ (during splitless injection), from $40^{\circ} \mathrm{C}$ to $60^{\circ} \mathrm{C}, 40^{\circ} \mathrm{C} \mathrm{min}{ }^{-1}, 60^{\circ} \mathrm{C}$ for $2 \mathrm{~min}$, from $60^{\circ} \mathrm{C}$ to $190^{\circ} \mathrm{C}, 2^{\circ} \mathrm{C} \mathrm{min}^{-1}$, from $190^{\circ} \mathrm{C}$ to $230^{\circ} \mathrm{C}, 5^{\circ} \mathrm{C} \mathrm{min}^{-1}, 230^{\circ} \mathrm{C}$ for $15 \mathrm{~min}$; injector $250^{\circ} \mathrm{C}$, Fid $250^{\circ} \mathrm{C}$, transfer line $230^{\circ} \mathrm{C}$, carrier helium $1 \mathrm{~mL} \mathrm{~min}^{-1}$; electron impact 
(EI) mode, $70 \mathrm{eV}$. The identification of volatiles was carried out by injection of commercial standards or others prepared in our laboratory (ethyl esters of 2hydroxyglutaric acid) (31). Higher alcohols were determined on distilled wine through gas-chromatographic analyses with FID detector (GC PerkinElmer Autosystem XL) (29). The identification of the volatile compounds of higher alcohols, esters and acids was only tentative, not absolute. All solvents and reagents were purchased from WWR International (Milan, Italy). Chemical and physical determinations were performed in triplicate.

Sensory analysis A descriptive method (Ente Nazionale Italiano di Unificazione, UNI 10957, 2003) was used to define the sensory profile of the experimental bottled wines in comparison to two wines obtained by conventional winemaking and purchased from a market. A descriptive panel of ten judges was employed. The judges were trained in some preliminary sessions, using different samples of IGT Sicilia Catarratto wines in order to develop a common vocabulary for the description of the sensory attributes of Catarratto wine samples and to familiarize themselves with scales and procedures. Each attribute term was extensively described and explained to avoid any doubt about the relevant meaning. On the basis of the frequency of citation (>60\%), 19 descriptors were selected to be inserted in the card: intensity of colour, odour intensity, odour complexity, off-odour, flowers, fresh fruits, mature fruits, citrus fruits, dry fruits, aromatic herbs, species (odour), sweet, acidity, bitter, salt (taste), hot and astringent (tactile in mouth) and off-flavour (taste). Terroir expression, was also evaluated.

The wine samples were randomly evaluated by assigning a score between 1 (absence of the sensation) and 9 (extremely intense) in individual booths under incandescent white lighting. The analysis was performed in triplicate. The resulting scores were averaged and compared. ANOVA test (Statistica software, StatSoft Inc., Tulsa, OK, USA) was applied to find significant differences among attributes of wines.

\section{RESULTS}

Microbiological analysis The evolution of microbial loads is reported in Table 1. TY recorded on grapes was $6.28 \mathrm{Log} \mathrm{CFU} \mathrm{g}^{-1}$ and increased of about one Log cycle after grape pressing. During alcoholic fermentation it still increased and the highest concentration (7.93 Log $\mathrm{CFU} \mathrm{mL}^{-1}$ ) was registered in correspondence of the racking (day 3 ). The level of yeast count was stable at approximately 7 Log CFU $\mathrm{mL}^{-1}$ until the end of fermentation and it decreased during the ageing of wine reaching the lowest value (4.57 Log CFU mL ${ }^{-1}$ ) at day 19. At bottling (34th day from the beginning of ageing) TY was not detectable. Grape berries showed a LAB concentration on MLO (3.11 Log CFU mL ${ }^{-1}$ ) higher than MRS (2.30 Log CFU mL $\mathrm{mL}^{-1}$ ) and GM17 (2.29 Log CFU $\left.\mathrm{mL}^{-1}\right)$; on the other hand, after grape crushing, LAB population increased more than one Log cycle onto all media. After two days of alcoholic fermentation, LAB reached the highest values (approximately 6 Log $\mathrm{CFU} \mathrm{mL}{ }^{-1}$ ). A significant decrease in concentration was registered for acidophilic LAB (2.70 Log $\mathrm{CFU} \mathrm{mL}^{-1}$ ) after racking, while the levels detected onto MRS and GM17 decreased after the fourth day of fermentation. An opposite behaviour was showed by $\mathrm{LAB}$ at the end of alcoholic

TABLE 1. Microbial loads $s^{\mathrm{a}}$ of samples collected during natural winemaking processes of Catarratto cultivar.

\begin{tabular}{lcccc}
\hline Steps of winemaking & \multicolumn{4}{c}{ Catarratto } \\
\cline { 2 - 5 } & WL & MRS & GM17 & MLO \\
\hline Grape berries & $6.28 \pm 0.72$ & $2.30 \pm 0.99$ & $2.29 \pm 0.34$ & $3.11 \pm 0.07$ \\
Must & $7.04 \pm 0.20$ & $4.07 \pm 0.05$ & $4.11 \pm 0.04$ & $4.08 \pm 0.04$ \\
Fermentation: & & & & \\
Day 1 - maceration & $6.98 \pm 0.03$ & $4.08 \pm 0.11$ & $4.10 \pm 0.41$ & $4.16 \pm 0.04$ \\
Day 2 - maceration & $7.20 \pm 0.30$ & $6.19 \pm 0.21$ & $6.07 \pm 0.20$ & $6.06 \pm 0.20$ \\
Day 3 - racking & $7.93 \pm 0.03$ & $6.12 \pm 0.09$ & $6.01 \pm 0.55$ & $2.70 \pm 0.55$ \\
Day 4 & $7.69 \pm 0.02$ & $2.53 \pm 0.33$ & $1.20 \pm 0.33$ & $1.73 \pm 0.33$ \\
Day 6 & $7.56 \pm 0.01$ & $3.43 \pm 0.13$ & $2.16 \pm 0.02$ & $1.30 \pm 0.02$ \\
Day 7 & $7.71 \pm 0.13$ & $3.10 \pm 0.56$ & $1.85 \pm 0.30$ & $3.10 \pm 0.30$ \\
Ageing: & & & & \\
Day 3 - clarification & $6.87 \pm 0.01$ & $1.02 \pm 0.88$ & $0.30 \pm 0.13$ & $1.50 \pm 0.13$ \\
Day 14 - transfer 1 & $4.01 \pm 0.12$ & $1.05 \pm 0.21$ & $1.34 \pm 0.50$ & $2.23 \pm 0.50$ \\
day 19 - transfer 2 & $4.57 \pm 0.04$ & $1.20 \pm 0.33$ & $1.38 \pm 0.12$ & $1.15 \pm 0.12$ \\
Bottling & n.d. & n.d. & n.d. & n.d. \\
\hline n.d. not detected (value & \multicolumn{1}{c}{ detection } & & \\
\end{tabular}

n.d., not detected (value $<$ detection limit of method).

${ }^{a}$ Log CFU g ${ }^{-1}$ for grape berries; Log CFU $\mathrm{mL}^{-1}$ for must and wine samples. fermentation, when they were found to increase their concentration, in particular onto MRS and MLO. During ageing a reduction of $\mathrm{LAB}$ population was observed onto all three media, till reaching values not detectable in correspondence of bottling.

Isolation, identification and distribution of yeasts A total of 867 colonies from WL agar were isolated, purified to homogeneity on the same medium used for plate count and separated on the basis of colony morphology. At least five cultures with different appearance from each sample were selected and 423 isolates were subjected to molecular identification. After restriction analysis of 5.8S-ITS region and 26S rRNA gene, the isolates were clustered in nine groups (Table 2). Eight of these groups were directly identified by comparison of the restriction bands with those available in literature (18): Aureobasidium pullulans (group I), Candida zemplinina (group II), Hanseniaspora guilliermondii (group III), Hanseniaspora uvarum (group IV), Metschnikowia pulcherrima (group VI), Pichia guilliermondii (group VII), Rhodotorula mucillaginosa (group VIII) and S. cerevisiae (group IX). The group $\mathrm{V}$ could not be identified by RFLP analysis and the identification at species level was concluded by sequencing of D1/D2 domain of the 26S rRNA gene which allotted the isolates into the species Issatchenkia terricola. This method was also applied to confirm previous species.

The distribution of yeast species and the highest concentrations estimated for each sample are reported in Table 2 . All nine species were easily detected on grape berries, but after pressing only three species ( $H$. guilliermondii, M. pulcherrima and $S$. cerevisiae) were present at dominating levels (the concentration estimated onto Petri dishes were the highest). S. cerevisiae resulted dominant alone during the entire alcoholic fermentation, even though the nonSaccharomyces (NS) yeasts belonging to A. pullulans, $H$. guilliermondii and $H$. uvarum were isolated until the second day of this phase of vinification. During the wine ageing, the species $S$. cerevisiae was found, at concentrations lower than those registered in fermentation, no longer than the third day. After clarification, the only yeast species isolated was $P$. guilliermondii. No yeast was isolated at bottling.

Typing and distribution of $\boldsymbol{S}$. cerevisiae strains The 179 isolates belonging to the species $S$. cerevisiae were further genetically characterized. The interdelta analysis was able to separate the isolates in 27 groups, while microsatellite multiplex PCR recognized 24 different groups (results not shown), showing a lower discriminatory power than the first technique. The distribution of the different strains of $S$. cerevisiae during winemaking showed a high biodiversity in terms of strains during the different steps of wine production (Fig. 1). Only four strains isolated from grapes (CTBRL 129) and must (CTBRL 63, CTBRL 87 and CTBRL 152) were identified during the alcoholic fermentation. A high variety of strains $(n=14)$ at dominating levels was found during the alcoholic fermentation, in particular at day 3 and 4 . At the clarification step, five strains that were not identified in the previous steps were detected.

All strains presented genotypic profiles different from that showed by commercial strains used as control (data not shown).

Isolation, identification and distribution of $\mathbf{L A B}$ On the basis of appearance, about five colonies per morphology were isolated from each medium used for LAB counts (MRS, GM17 and MLO) at the highest dilutions of samples. A total of 997 bacterial cultures were picked up from agar plates and propagated in the broth media corresponding to those used for counts, applying the same incubation conditions. The cultures were purified as reported above and the microscopic inspection allowed their separation in 774 rods and 223 cocci. After Gram characterization and catalase testing, 689 rods and 191 cocci were considered presumptive LAB cultures, as being gram-positive and catalase negative. 
TABLE 2. Molecular identification and distribution ${ }^{\mathrm{a}}$ of yeasts.

\begin{tabular}{|c|c|c|c|c|c|c|c|c|c|c|c|}
\hline \multirow{2}{*}{$\begin{array}{l}\text { R.P. (no. of } \\
\text { isolates) }\end{array}$} & \multirow{2}{*}{$\begin{array}{l}\text { Isolate } \\
\text { code }\end{array}$} & \multirow{2}{*}{$\begin{array}{l}\text { 5.8S-ITS } \\
\text { PCR }^{\mathrm{b}}\end{array}$} & \multicolumn{3}{|c|}{ Size of restriction fragment } & \multirow{2}{*}{$\begin{array}{l}26 \mathrm{~S} \\
\mathrm{PCR}^{\mathrm{c}}\end{array}$} & \multicolumn{2}{|c|}{ Size of restriction fragment } & \multirow[t]{2}{*}{ Species (\% identity) ${ }^{d}$} & \multirow[t]{2}{*}{ Acc. No. } & \multirow[t]{2}{*}{ Distribution } \\
\hline & & & Cfol & HaelII & Hinfl & & Hinfl & Msel & & & \\
\hline I (42) & CtbrL8 & 620 & $180+160+90$ & $470+150$ & $280+160+130$ & 1100 & $\begin{array}{l}480+390+ \\
180+50\end{array}$ & $600+380+100+50$ & $\begin{array}{l}\text { Aureobasidium } \\
\text { pullulans (99) }\end{array}$ & JX423556 & $\mathrm{Gb}(6) ; \mathrm{F} 1(6)$ \\
\hline II $(20)$ & CtbrL76 & 480 & $220+110+60$ & 480 & $240+240$ & 1100 & $\begin{array}{l}340+320+ \\
210+90+50\end{array}$ & $710+140+70$ & $\begin{array}{l}\text { Candida zemplinina } \\
\text { (99) }\end{array}$ & JX423554 & $\mathrm{Gb}(6)$ \\
\hline III (164) & CtrbrL78B & 750 & $320+310+105$ & 750 & $\begin{array}{l}350+180+ \\
160+60\end{array}$ & 1120 & n.c. & n.c. & $\begin{array}{l}\text { Hanseniaspora } \\
\text { guilliermondii }^{\text {b }} \\
\text { (99) }\end{array}$ & JX423565 & $\begin{array}{l}\mathrm{Gb}(6) ; \mathrm{M}(7) ; \mathrm{F} 1(6) \\
\mathrm{F} 2(7)\end{array}$ \\
\hline IV (78) & CtrbrL65 & 750 & $320+310+105$ & 750 & $350+200+180$ & 1100 & $390+180$ & $500+420+100+50$ & $\begin{array}{l}\text { Hanseniaspora } \\
\text { uvarum }^{\mathrm{b}} \text { (99) }\end{array}$ & JX423558 & $\mathrm{Gb}(6) ; \mathrm{F} 1(6)$ \\
\hline $\mathrm{V}(23)$ & CtrbrL79 & 460 & $125+100+90+80$ & $300+120$ & $220+90$ & 1100 & $340+250+220$ & $820+210+100+50$ & $\begin{array}{l}\text { Issatchenkia terricola } \\
\text { (99) }\end{array}$ & JX423555 & $\mathrm{Gb}(6)$ \\
\hline VI (40) & CtrbrL43 & 400 & $205+100+95$ & $280+100$ & $200+190$ & 1100 & $340+250+220$ & $550+250+140+50$ & $\begin{array}{l}\text { Metschnikowia } \\
\text { pulcherrima (98) }\end{array}$ & JX423553 & $\mathrm{Gb}(6) ; \mathrm{M}(7)$ \\
\hline VII (121) & CtrbrL5 & 600 & $300+265+60$ & $400+115+90$ & $320+300$ & 1100 & $490+230+170$ & $680+370+50$ & $\begin{array}{l}\text { Pichia guilliermondii } \\
\text { (99) }\end{array}$ & JX423568 & $\mathrm{Gb}(6), \mathrm{A} 14(4) ; \mathrm{A} 19(4)$ \\
\hline VIII (20) & CtrbrL26B & 640 & $320+220$ & $420+220$ & $355+210+75$ & 1100 & $510+420+210$ & $\begin{array}{l}380+270+240+ \\
140+70\end{array}$ & $\begin{array}{l}\text { Rhodotorula } \\
\text { mucillaginosa } \\
(100)\end{array}$ & JX423557 & $\mathrm{Gb}(6)$ \\
\hline IX (359) & CtrbrL56 & 880 & $360+340+130$ & $\begin{array}{l}320+240+ \\
180+140\end{array}$ & $360+110$ & 1100 & $490+210+190$ & n.c. & $\begin{array}{l}\text { Saccharomyces } \\
\text { cerevisiae (100) }\end{array}$ & JX423563 & $\begin{array}{l}\mathrm{Gb}(6) ; \mathrm{M}(7) ; \mathrm{F} 1(6) ; \\
\mathrm{F} 2(7) ; \mathrm{F} 3(7) ; \mathrm{F} 4(7) ; \\
\mathrm{F} 6(7) ; \mathrm{F} 7(7) ; \mathrm{A} 3(6)\end{array}$ \\
\hline
\end{tabular}

All values for the 5.8S-ITS PCR, 26S PCR and restriction fragments are given in bp.

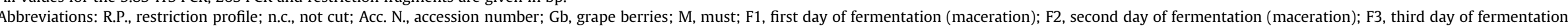
(racking); F4, fourth day of fermentation; F6, sixth day of fermentation; F7, seventh day of fermentation; A3, third day of ageing (clarification); A14, 14th day of ageing (transfer 1); A19, 19th day of ageing (transfer 2).

a The number reported between parentheses refers to the highest concentration (Log cycle) of detection.

The 5.8S-ITS gene was also digested with Ddel endonuclease confirming the restriction profile reported in literature (18).

c Restriction enzymes ApaI did not produce any cut fragment.

d According to BlastN search of D1/D2 26S rRNA gene sequences in NCBI database. 


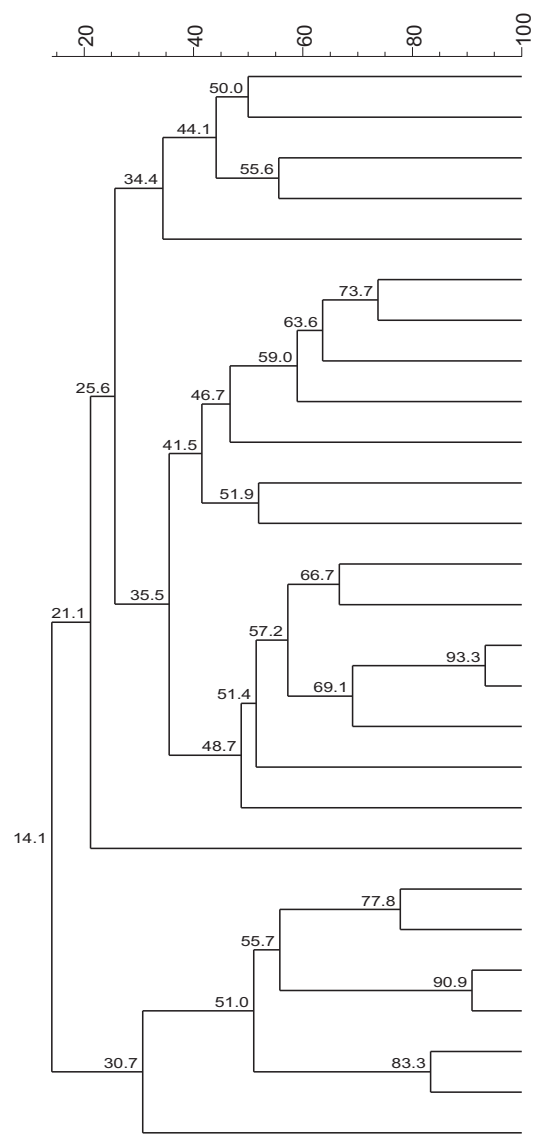

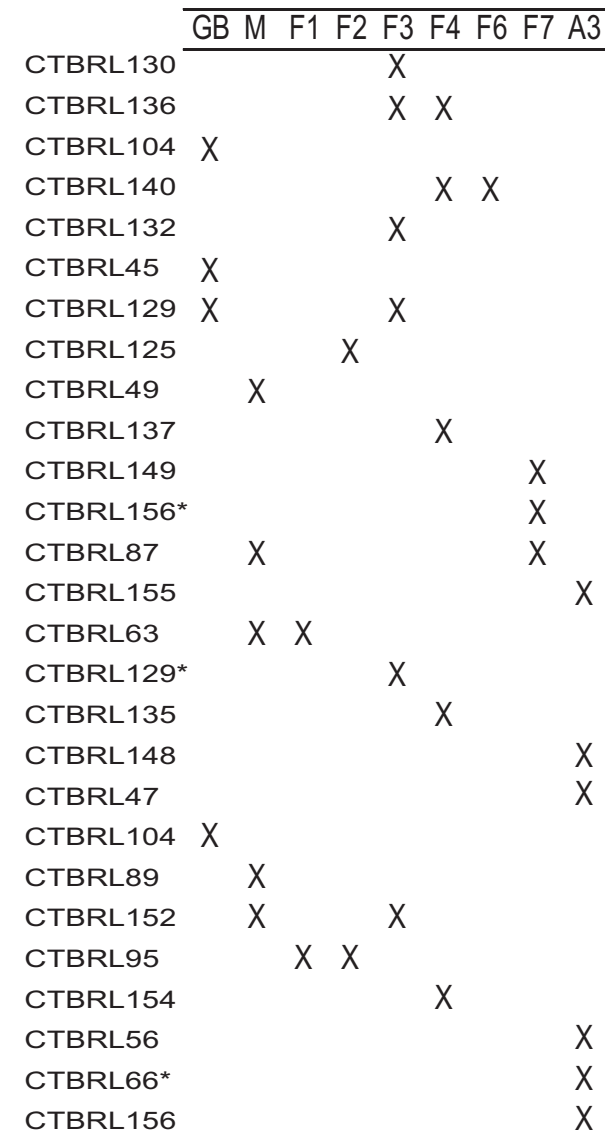

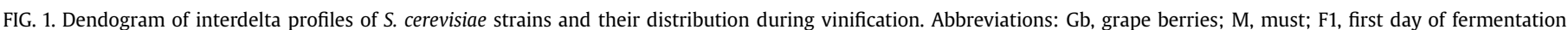

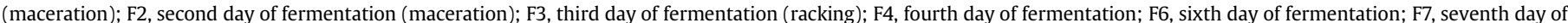
fermentation; A3, third day of ageing (clarification).

The combinations of the phenotypic characters considered allowed the separation of the $880 \mathrm{LAB}$ cultures into 3 groups (Table 3), two for rods and one for cocci. $\mathrm{CO}_{2}$ production from glucose was scored negative for the isolates of group $\mathrm{C}$ which were tested for growth in presence of pentose sugars, that evidenced their facultative heterofermentative metabolism.

About $30 \%$ of the isolates of each phenotypic group, 263 in total, was subjected to RAPD analysis using primer M13 (results not shown). The isolates analysed were divided into eight main clusters for the three phenotypic groups: two clusters for group A, one for group B and five for group C (Fig. 2). One strain for each RAPD profile was identified at species level by $16 S$ rRNA gene sequencing. The BLAST search shared a percentage of identity with sequences available in the NCBI database of at least 97\%. Three species belonging to Leuconostoc mesenteroides, Lactobacillus hilgardii and Lactobacillus plantarum were found.

TABLE 3. Phenotypic grouping of LAB.

\begin{tabular}{lccc}
\hline Characters & \multicolumn{3}{c}{ Clusters } \\
\cline { 2 - 4 } & $\mathrm{A}(n=191)$ & $\mathrm{B}(n=51)$ & $\mathrm{C}(n=638)$ \\
\hline Morphology & Coccus & Rod & Rod \\
Growth: & + & & + \\
$15^{\circ} \mathrm{C}$ & - & + & - \\
$45^{\circ} \mathrm{C}$ & - & - & n.d. \\
$\mathrm{pH} 9.6$ & + & n.d. & n.d. \\
$6.5 \% \mathrm{NaCl}$ & + & + & - \\
$\mathrm{CO}_{2}$ from glucose & n.d. & n.d. & + \\
Growth in presence of pentose & & & \\
carbohydrates & & &
\end{tabular}

Abbreviation: $n$, number of isolates; n.d., not determined.

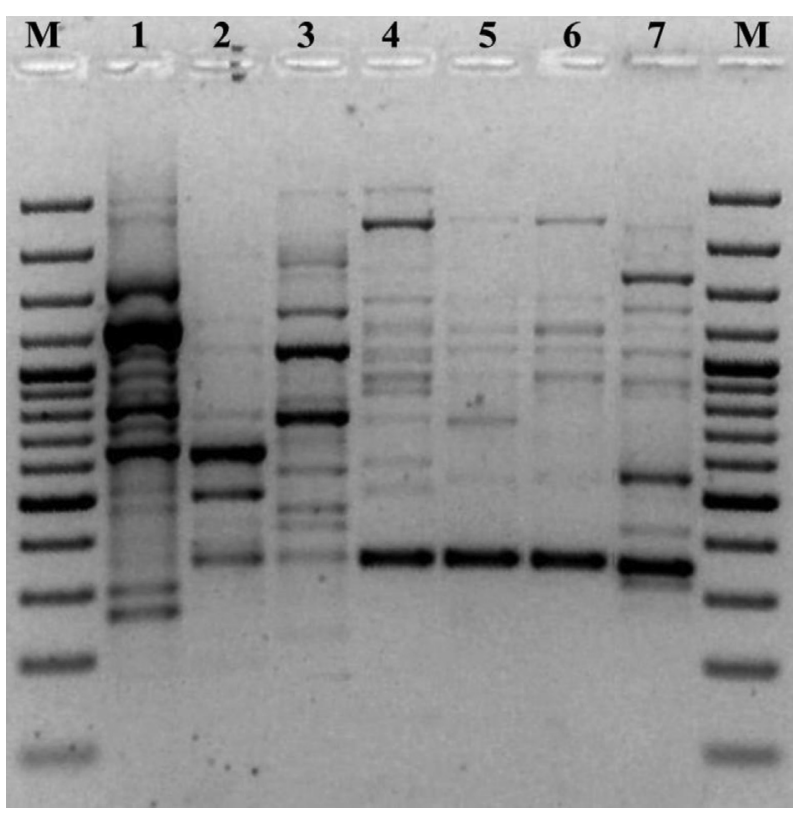

FIG. 2. PCR-RAPD profiles of LAB species. Lanes: M, molecular marker GeneRuler $100 \mathrm{bp}$ DNA Ladder (Fermentas) Lanes 1-7 represent RAPD-PCR groups: 1, group I strain CtbrBL226; 2, group II strain CtbrBL480; 3, group III strain CtbrBL372; 4, group IV strain CtbrBL22; 5, group V strain CtbrBL103; 6, group VI strain CtbrBL25; 7, group VII strain CtbrBL487. 
The distribution of LAB species and their concentration estimated for each sample are shown in Table 4 . The three species were all found on grape berries. L. hilgardii was no more detected during vinification. On the contrary, L. plantarum was the species most encountered during the entire alcoholic fermentation reaching the highest values of concentration during the first days of fermentation. Also L. mesenteroides was found at high dilutions of samples until the sixth day of fermentation. During ageing, L. plantarum was the only LAB species detected, but at lower concentrations than fermentation.

Chemical conventional parameters The conventional parameters of samples collected during winemaking are reported in Table 5. Values of pH, TTA and tartaric acid were in the range of those commonly reported for commercial wines, instead total $\mathrm{SO}_{2}$ and free $\mathrm{SO}_{2}$ values were very low due to the absence of exogenous sulphides. Reducing sugars rapidly decreased during the first days of fermentation till bottling when these sugars were no more detected. On the contrary, ethanol and glycerol showed a rapid increase from the second day of fermentation $\left(1.1 \% \mathrm{v} \mathrm{v}^{-1}\right.$ of ethanol, $0.88 \mathrm{~g} \mathrm{~L}^{-1}$ of glycerol) to racking $\left(5.8 \% \mathrm{v} \mathrm{v}^{-1}\right.$ of ethanol, $4.98 \mathrm{~g} \mathrm{~L}^{-1}$ of glycerol). At the end of winemaking, ethanol reached $12.67 \%\left(\mathrm{v} \mathrm{v}^{-1}\right)$ and glycerol $7.19 \mathrm{~g} \mathrm{~L}^{-1}$. PAN concentration varied greatly during the first two days of alcoholic fermentations till seventh day of winemaking at which it was not detectable. VA content was almost constant during winemaking and its maximum concentration $\left(0.36 \mathrm{~g} \mathrm{~L}^{-1}\right)$ was estimated at bottling. Malic acid content was constant till the third day of ageing after that it rapidly decreased till bottling $\left(0.1 \mathrm{~g} \mathrm{~L}^{-1}\right)$. Lactic acid concentration showed an irregular behaviour: the maximum level (1.65 $\mathrm{g} \mathrm{L}^{-1}$ ) was registered at the second day of fermentation, after that it decreased till the fourth day $\left(0.28 \mathrm{~g} \mathrm{~L}^{-1}\right)$ and, subsequently, it showed an increasing trend until bottling ( $\left.1.63 \mathrm{~g} \mathrm{~L}^{-1}\right)$.

Phenolic compounds Fig. 3 graphically reports the measurements of the HCTA. The trans-caffeil tartaric acid showed the highest increase during the entire period of sampling. Its maximum values (approximately of $60 \mathrm{mg} \mathrm{L}^{-1}$ ) were observed during the last three steps of fermentation after that trans-caffeil tartaric acid showed a rapid decrease till bottling $\left(43.11 \mathrm{mg} \mathrm{L}^{-1}\right)$. Also for 2-S-glutationil-trans-caffeil tartaric acid, known as grape reaction product (GPR) (30), was observed a rapid increase at the first day of alcoholic fermentation $\left(40.99 \mathrm{mg} \mathrm{L}^{-1}\right)$, while its value decreased until the end of winemaking (19.63 $\left.\mathrm{mg} \mathrm{L}^{-1}\right)$. Other compounds such as trans-p-cumaril tartaric acid, cis-p-cumaril tartaric and caffeil-tartaric acid showed a low increase at the first day of alcoholic fermentation while its concentration did not greatly vary until bottling. Free caffeic and trans-feruil tartaric acid were characterized by the lowest values during the entire winemaking.

VOCs and sensory evaluation VOCs (Table 6) were composed of alcohols, esters, acetate esters and acids that were analysed at principal steps of winemaking. Alcohols were principally represented by higher alcohols that showed an increasing trend until bottling. Among this group the highest concentrations were reached by isoamylic alcohol and isobutanol, while 1-hexanol resulted the most abundant compound of the rest of alcohols. Also levels of esters and acetate esters increased until bottling. In particular, diethyl succinate, ethyl octanoate, 4-OH-butyrate ethyl, hexanoate and ethyl decanoate showed the highest concentrations among esters, while ethyl acetate represented more than $97 \%$ of total acetate esters. Except for decanoic acid content that was almost constant, all acids reached high level of concentrations showing an increasing trend from racking to bottling. The results of sensory analysis of wine samples are represented in Fig. 4. The majority of attributes examined were almost similar among wines. The significant $(p<0.05)$ differences among samples were found only for odour complexity, mature fruits, aromatic herbs and terroir expression that were higher in experimental wine respect to other samples. All wines did not show off-odours and off-flavours.

\section{DISCUSSION}

Wine quality can be affected by the growth of different yeasts originating from the microbial communities hosted on grapes (15). The use of spontaneous fermentation represents a valuable technological alternative to the application of commercial starter cultures responsible for wine flavour standardization, as well as to the selected autochthonous cultures. The autochthonous yeasts could positively contribute to wine quality and typicality but they are not able to represent completely the inter- and intra-specific biodiversity that characterize the spontaneous fermentations.

The present study was performed to investigate a natural winemaking of Catarratto IGT Sicilia for its microbiological and

TABLE 4. Molecular identification and distribution ${ }^{\mathrm{a}}$ of LAB.

\begin{tabular}{|c|c|c|c|c|c|c|c|c|}
\hline \multirow[t]{3}{*}{ Species } & \multirow[t]{3}{*}{ Isolate code } & \multicolumn{4}{|c|}{ Genotipic identification } & \multicolumn{3}{|c|}{ Distribution of LAB on different media } \\
\hline & & \multirow{2}{*}{$\begin{array}{l}\text { RAPD-PCR } \\
\text { profile }\end{array}$} & \multirow{2}{*}{$\begin{array}{l}\text { No. of } \\
\text { isolates }\end{array}$} & \multicolumn{2}{|c|}{ 16S rRNA sequencing } & \multirow[t]{2}{*}{ MRS } & \multirow[t]{2}{*}{ GM17 } & \multirow[t]{2}{*}{ MLO } \\
\hline & & & & $\begin{array}{c}\% \\
\text { Omology }\end{array}$ & $\begin{array}{l}\text { Acc. } \\
\text { Number }\end{array}$ & & & \\
\hline \multirow{2}{*}{$\begin{array}{l}\text { Leuconostoc } \\
\text { mesenteroides }\end{array}$} & CtbrBL226 & Group I & 37 & 99 & JX426116 & $\mathrm{Gb}(2)$ & & $\mathrm{Gb}(3)$ \\
\hline & CtbrBL480 & Group II & 154 & 99 & JX423551 & $\mathrm{Gb}(2)$ & $\begin{array}{l}\mathrm{Gb}(2) ; \mathrm{M}(4) ; \mathrm{F} 1(4) \\
\mathrm{F} 2(6) ; \mathrm{F} 3(6) ; \mathrm{F} 4(1)\end{array}$ & \\
\hline $\begin{array}{l}\text { Lactobacillus } \\
\text { hilgardii }\end{array}$ & CtbrBL372 & Group II & 51 & 99 & JX423552 & $\mathrm{Gb}(2)$ & & $\mathrm{Gb}(3)$ \\
\hline \multirow{4}{*}{$\begin{array}{l}\text { Lactobacillus } \\
\text { plantarum }\end{array}$} & CtbrBL22 & Group IV & 22 & 99 & JX426117 & $\mathrm{Gb}(2)$ & & $\mathrm{Gb}(3)$ \\
\hline & CtbrBL103 & Group V & 25 & 99 & JX426118 & $\mathrm{Gb}(2)$ & & $\mathrm{Gb}(3)$ \\
\hline & CtbrBL25 & Group VI & 145 & 99 & JX426119 & $\mathrm{Gb}(2) ; \mathrm{M}(4) ; \mathrm{F} 1(4) ; \mathrm{F} 2(6)$ & & $\mathrm{Gb}(3) ; \mathrm{M}(4) ; \mathrm{F} 1(4) ; \mathrm{F} 2(6)$ \\
\hline & CtbrBL487 & Group VII & 446 & 99 & JX423550 & $\begin{array}{l}\mathrm{Gb}(2) ; \mathrm{F} 3(6) ; \mathrm{F} 4(2) ; \mathrm{F} 6(3) ; \\
\mathrm{F} 7(3) \mathrm{A} 3(1) ; \mathrm{A} 14(1) \\
\mathrm{A} 19(1)\end{array}$ & $\begin{array}{l}\text { F6(2); F7(1); A3(1); } \\
\text { A14(1); A19(1) }\end{array}$ & $\begin{array}{l}\mathrm{Gb}(3) ; \mathrm{F} 3(2) ; \mathrm{F} 4(1) ; \mathrm{F} 6(1) ; \\
\mathrm{F} 7(3) \mathrm{A} 3(1) ; \mathrm{A} 14(2) ; \\
\mathrm{A} 19(1)\end{array}$ \\
\hline
\end{tabular}

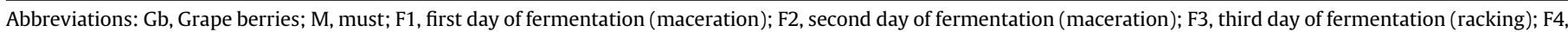

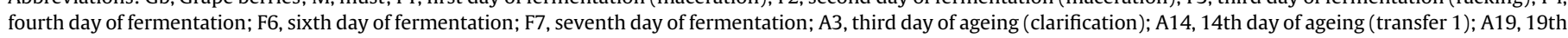
day of ageing (transfer 2).

a The number reported between parentheses refers to the highest concentration (Log cycle) of detection.

b According to BlastN search of 16S rRNA gene sequences in NCBI database. 


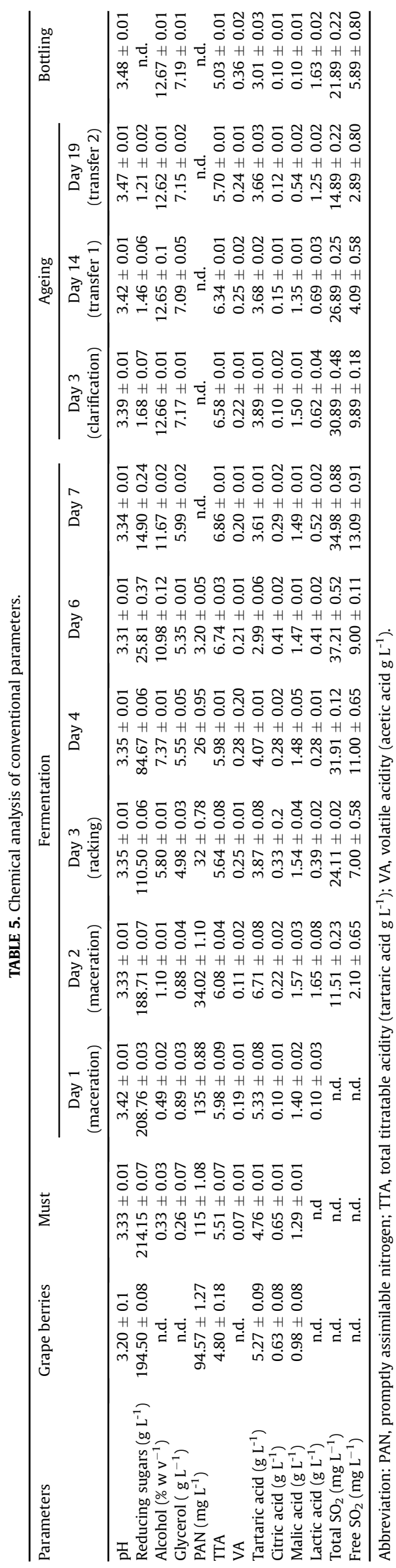

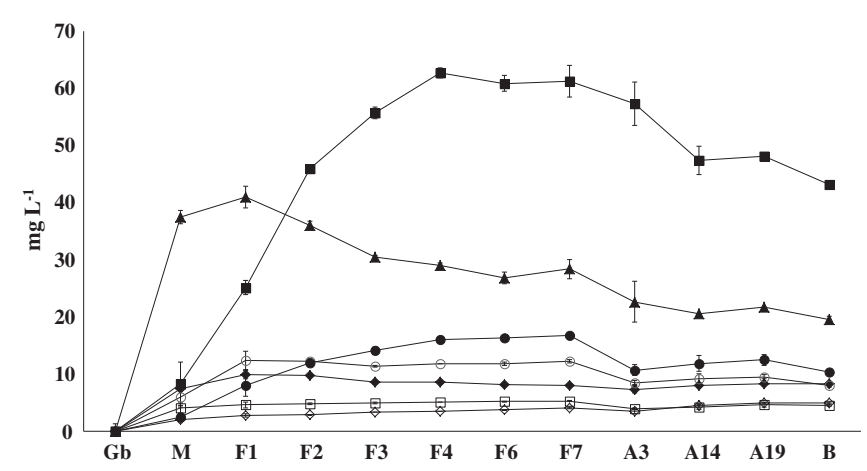

FIG. 3. Distribution of hydroxy cinnamic acids during winemaking. Abbreviations: Gb, grape berries; M, must; F1, first day of fermentation (maceration); F2, second day of fermentation (maceration); F3, third day of fermentation (racking); F4, fourth day of fermentation; F6, sixth day of fermentation; F7, seventh day of fermentation; A3, third day of ageing (clarification); A14, 14th day of ageing (transfer 1); A19, 19th day of ageing (transfer 2); B, bottling. Symbols: closed rhombuses, caffeil tartaric acid; closed squares, trans-caffeil tartaric acid; closed triangles, 2-S-glutationil-trans-caffeil tartaric acid; open circles, cis-p-cumaril tartaric acid; closed circles, trans-p-cumaril tartaric acid; open rhombuses, trans-feruil tartaric acid; open squares, caffeic acid.

chemical composition. To this purpose, the vinification based on spontaneous fermentation and carried out without any oenological additives was monitored at winery-scale. Samples were collected at each step of production, from grape harvest to wine bottling.

Microbiological results evidenced a substantial concentrations of yeasts during the entire process with values higher than 7 Log ( $\mathrm{CFU} \mathrm{mL} \mathrm{m}^{-1}$ ) during the alcoholic fermentation, while a decrease was registered from clarification to bottling. Even though the experimental vinification was carried out following the criteria of natural wine, yeast evolution during the entire process was superimposable to that registered during conventional winemaking carried out with starter cultures and chemical additives (31).

$\mathrm{LAB}$ increased during the first steps of winemaking with the maximum value of $6.12 \mathrm{Log}\left(\mathrm{CFU} \mathrm{mL} \mathrm{m}^{-1}\right)$ registered onto MRS at the second day of alcoholic fermentation, but soon after, they showed a decreasing trend until bottling. To our knowledge, no work has shown the maximum increase of LAB concentration during the tumultuous phase of alcoholic fermentation. LAB occur naturally on grapes and into must just pressed at low concentrations $(32,33)$. These bacteria have a defining role in wine production since their activities can be beneficial or detrimental for the quality of wine, depending on the species and/or strain and also on the stage of the vinification at which they develop (34). The growth of LAB in wine is influenced by many factors such as temperature, alcohol concentration, $\mathrm{pH}$, nutrient availability and sulphur dioxide (32). Generally, during alcoholic fermentation, the LAB presence is detected at low concentration due to increase of yeast population and the use of $\mathrm{SO}_{2}$. However, several works showed that yeasts grow faster than $\mathrm{LAB}$ even in absence of $\mathrm{SO}_{2}$ due to their ability to rapidly adapt at the selective conditions of grape must (31).

The process of yeast isolation resulted in the collection of 1184 cultures. After restriction analysis of two distinct gene, nine yeast groups were recognized. The isolates belonging to the species I. terricola (group V) were characterized by atypical restriction profiles of 5.8S-ITS, a phenomenon that is not surprising for yeasts in this DNA region, since many authors observed this behaviour in several strains (34-36). At the end of the identification process, nine species belonging to eight genera (Aureobasidium, Candida, Hanseniaspora, Issatchenkia, Metschnikowia, Pichia, Rhodotorula and Saccharomyces) were found. The yeast community present on the grapes was characterized by the highest interspecific biodiversity compared to the communities during the several phases of wine production. As previously stated by other authors $(37,38)$, non- 
TABLE 6. Volatile organic compounds.

\begin{tabular}{|c|c|c|c|c|}
\hline \multirow[t]{2}{*}{ Compounds } & \multicolumn{3}{|c|}{ Fermentation } & \multirow[t]{2}{*}{ Bottling } \\
\hline & Day-3 (racking) & Day-4 & Day-7 & \\
\hline Higher alcohols (mg L $\left.{ }^{-1}\right)$ & 107.65 & 240.54 & 243.42 & 297.22 \\
\hline Isoamylic alcohol & $47.81 \pm 1.21$ & $152.31 \pm 0.94$ & $155.37 \pm 1.23$ & $179.67 \pm 1.11$ \\
\hline Isobutanol & $28.58 \pm 0.61$ & $43.70 \pm 1.09$ & $38.41 \pm 1.31$ & $62.88 \pm 3.33$ \\
\hline n-Propanol & $18.00 \pm 0.88$ & $23.38 \pm 0.60$ & $18.38 \pm 0.98$ & $25.93 \pm 1.34$ \\
\hline Phenyl-2-ethanol & $13.26 \pm 0.38$ & $21.15 \pm 0.60$ & $31.26 \pm 0.89$ & $28.74 \pm 0.81$ \\
\hline Other alcohols $\left(\mu \mathrm{g} \mathrm{L}^{-1}\right)$ & 819.01 & 1256.19 & 1181.09 & 1370.91 \\
\hline 1-Hexanol & $773.77 \pm 54.71$ & $1155.16 \pm 81.68$ & $1083.09 \pm 76.59$ & $1246.71 \pm 88.16$ \\
\hline 3-Methyl pentan-1-olo & n.d. & $21.20 \pm 1.05$ & $33.89 \pm 1.68$ & $54.48 \pm 2.70$ \\
\hline cis-3-Hexenol & $19.82 \pm 1.26$ & $32.54 \pm 2.07$ & $29.10 \pm 1.85$ & $32.76 \pm 2.08$ \\
\hline trans-3-Hexenol & $25.42 \pm 1.62$ & $47.29 \pm 3.01$ & $35.01 \pm 2.23$ & $36.96 \pm 2.35$ \\
\hline Esters $\left(\mu \mathrm{g} \mathrm{L}^{-1}\right)$ & 3589.15 & 8703.08 & 12097.11 & 24070.83 \\
\hline Diethyl malate & n.d. & $72.13 \pm 2.55$ & $103.60 \pm 3.66$ & $62.02 \pm 2.19$ \\
\hline Diethyl succinate & $32.30 \pm 1.83$ & $2671.43 \pm 91.12$ & $2463.93 \pm 82.81$ & $15506.04 \pm 877.15$ \\
\hline Ethyl 4-OH-butyrate & $154.25 \pm 7.64$ & $495.94 \pm 24.55$ & $2279.18 \pm 112.81$ & $1642.22 \pm 81.29$ \\
\hline Ethyl 9-decanoate & n.d. & $311.96 \pm 13.24$ & $339.82 \pm 14.42$ & $292.56 \pm 12.41$ \\
\hline Ethyl decanoate & $582.37 \pm 24.71$ & $1039.67 \pm 44.11$ & $1359.48 \pm 57.68$ & $1526.01 \pm 64.74$ \\
\hline Ethyl hexanoate & $1048.28 \pm 44.47$ & $1475.06 \pm 62.58$ & $1751.93 \pm 74.33$ & $1097.83 \pm 46.58$ \\
\hline Ethyl lactate & $50.57 \pm 2.86$ & $295.49 \pm 16.72$ & $322.18 \pm 18.23$ & $782.58 \pm 44.27$ \\
\hline Ethyl octanoate & $1721.38 \pm 121.72$ & $2341.40 \pm 165.56$ & $3476.99 \pm 245.86$ & $3161.57 \pm 223.56$ \\
\hline Acetate Esters $\left(\mu \mathrm{g} \mathrm{L}^{-1}\right)$ & 13246.81 & 84346.42 & 114903.07 & 145431.60 \\
\hline Ethyl acetate & $9150.11 \pm 379.21$ & $79580.21 \pm 933.01$ & $110150.09 \pm 776.12$ & $141650.02 \pm 811.03$ \\
\hline Hexyl acetate & $130.00 \pm 7.35$ & $130.03 \pm 7.36$ & $102.61 \pm 5.80$ & $85.22 \pm 4.82$ \\
\hline Isoamyl acetate & $1401.36 \pm 49.55$ & $2082.45 \pm 73.63$ & $2104.09 \pm 74.39$ & $2251.80 \pm 79.61$ \\
\hline Phenyl-2-ethanol acetate & $2565.34 \pm 181.40$ & $2553.73 \pm 180.58$ & $2546.28 \pm 180.05$ & $1444.56 \pm 102.15$ \\
\hline Acids $\left(\mu \mathrm{g} \mathrm{L}^{-1}\right)$ & 12316.04 & 12844.36 & 18775.80 & 17724.96 \\
\hline Butyric acid & n.d. & $32.16 \pm 1.14$ & $28.49 \pm 1.01$ & $35.39 \pm 1.25$ \\
\hline Decanoic acid & $3981.91 \pm 197.09$ & $2383.43 \pm 117.97$ & $4270.78 \pm 211.39$ & $3506.01 \pm 173.54$ \\
\hline Hexanoic acid & $2724.18 \pm 96.31$ & $4118.60 \pm 145.61$ & $4826.92 \pm 170.66$ & $5205.97 \pm 184.06$ \\
\hline Octanoic acid & $5609.95 \pm 238.01$ & $6310.17 \pm 267.72$ & $9649.61 \pm 309.40$ & $8977.59 \pm 380.89$ \\
\hline
\end{tabular}

Saccharomyces (NS) yeasts were dominant on grapes and in must soon after pressing. Among NS yeasts, Hanseniaspora guilliermondii was the main species found until the second day of vinification confirming a general behaviour observed during other spontaneous fermentations (39) carried out in warm climates as well as in Sicily. On the other hand, it is interesting to note that the entire alcoholic fermentation was dominated by $S$. cerevisiae. This species is commonly recognized as the main technological yeast due to its high vigour and power fermentation as well as its low production of acetic acid and off-flavour. Then, its dominance during alcoholic fermentation could represent a guarantee of quality of wines both from a microbiological and chemical point of view. In order to investigate whether the selection due to the winemaking process

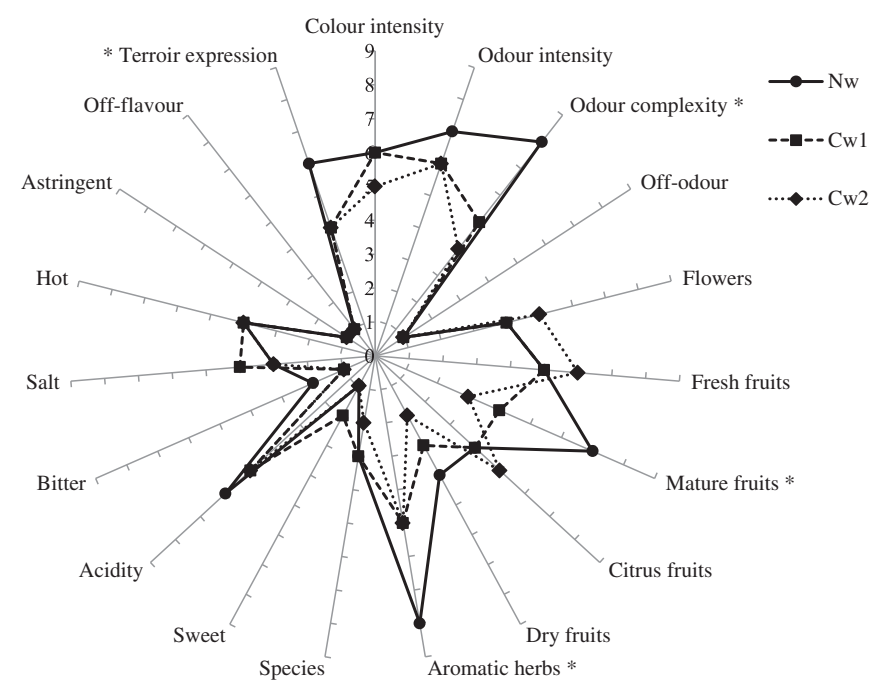

FIG. 4. Sensory profiles of wines. Nw, natural wine; Cw1 and Cw2, conventional wines. was defining also on the strain composition, S. cerevisiae community was analysed at intraspecies level. During the alcoholic fermentation, a high number of strains at dominating levels was found, then the intra-specific diversity of $S$. cerevisiae characterizing the natural winemaking under study resulted significantly higher than that described in conventional winemaking. The biodiversity, in terms of $S$. cerevisiae strains, represents an important aspect for wine quality since a more strains together may significantly affect the flavour and complexity of wine due to their enzymatic activities. After the third day of ageing, $P$. guilliermondii was the only yeast species isolated; it is generally associates to wine environments and also used in mixed culture with S. cerevisiae (40).

In our study, the biodiversity of LAB population during the vinification process was also evaluated. $L A B$ were phenotypically divided into three groups corresponding to three LAB species (L. mesenteroides, $L$. hilgardii and $L$. plantarum) that are commonly associated with wine environments (31). Among these, L. plantarum was the species most frequently isolated. This species has been found to grow during manufacturing of other wines due to its ethanol tolerance and acidophilic characteristics (41).

The vinification process was also monitored by chemical analysis and the results could be related to the metabolic activities of both yeast and LAB populations. The sugar consumption and the ethanol production showed a regular trend until bottling. Furthermore, the chemical analysis of samples revealed, after racking, a consistent production of glycerol, at desirable level. Glycerol is produced through the glycero-pyruvic fermentation carried out by yeasts (42). Generally, glycerol production is registered into grape musts characterized by high level of $\mathrm{SO}_{2}$ and fermented by starters grown in aerobic condition (31) and during the first phase of the alcoholic fermentation. Final glycerol content into wine is influenced by many factors depending on grape cultivar, fermentation temperature, sulphur dioxide addition as well as nitrogen and micronutrient concentrations (43). Furthermore, glycerol content in wine seems to be more strictly related to the yeast strains that dominate the fermentation process and than to the 
yeast concentration (44). In our study, a low glycerol production was also registered at the clarification phase (A3 sampling step) during the decrease of the yeast concentration. Glycerol production is not limited to the phase during which a yeast increase is registered, since it represents a part of the total glycerol concentration produced during winemaking. In addition, the low oxygen availability during the ageing process could positively affect the glycerol production by yeasts $(44,45)$.

However, when its concentration is higher than $5.2 \mathrm{~g} \mathrm{~L}^{-1}$, glycerol plays a positive role in winemaking because provides the wine with fullness, sweetness and roundness sensations (46). Different yeast species producers of high amounts of glycerol from sugars $(47,48)$ may found application to reduce the ethanol content of wines produced by grape musts characterized by high sugar content, such as those produced in southern Italy.

The concentration of lactic acid showed an irregular behaviour during winemaking. It could be due to the activities of both yeast and LAB. In particular, a significant increase of lactic acid, associated to the low level of VA, was registered at the racking phase. This could be due to the homolactic fermentation of sugars carried out by $L$. plantarum. However, LAB counts decreased and lactic acid content showed a rapid reduction probably because of the metabolic activities of yeasts (49) that reached high concentrations throughout the alcoholic fermentation until the clarification phase.

During ageing, LAB showed a very low concentration even though their enzymatic activity was revealed by the change in acid concentrations. Generally, the high ethanol content of wine registered during ageing could significantly inhibit the LAB growth as well as their metabolic activities. However, some studies showed that the chemical conversion of lactic acid into malic acid takes place also at low bacterial concentration and under stressing condition (50) as well as during different phases of winemaking (51). Furthermore, $L$. plantarum represents the first species characterized by production of malo-lactic enzymes (52) and, recently, it has been employed to carry out the malo-lactic fermentation as an alternative to the species Oenococcus oeni (53).

VOCs were also monitored during the vinification. Esters are of paramount importance to define the sensorial complexity of wines such as diethyl succinate (baked apple smell) and fatty acid esters (honey and wax smell). Higher alcohols, such as 1-hexanol, also contribute positively to the definition of the final profile of wine (herbaceous smell) if its concentration does not exceed $400 \mathrm{mg} \mathrm{L}^{-1}$ (54). The monitoring of HCTA was also performed since, in general, their concentration increases after the maceration phase and they could represent a risk for wine quality when they are oxidased to brown pigments and to volatile phenols (off-odours) by polyphenol oxidase (55). GPR compound, one of the most abundant HCTA detected into Catarratto wine, represents a precursor for antioxidant compounds.

In conclusion, the present study provides a complete overview of yeast and LAB populations and chemical compounds characterizing a natural winemaking process. The yeast distribution as well as the sensorial and chemical analysis showed the possibility to carry out a natural winemaking also without commercial strain starters and oenological additives. LAB concentration, in particular that of $L$. plantarum, was found at high concentrations during the tumultuous phase of alcoholic fermentation, and this report is the first on this observation. As long as the cellar management is constant, on the basis of the results showed, the natural process could represent a valid alternative to the conventional winemaking to preserve the typicality of wine.

\section{ACKNOWLEDGMENTS}

The authors wish to thank Nino Barraco, owner of Azienda Agricola Barraco (Marsala, TP, Italy), Dr. Vito Falco and Dr. Alberto
Parrinello of Centro di Ricerca per l'Innovazione della Filiera vitivinicola Ernesto del Giudice (Marsala, TP, Italy) for their technical support during chemical analysis and Dr. Giuseppe Bennardo for his support in microbiological and chemical analysis.

\section{References}

1. Pereira, G. E., Gaudillère, J. P., Pieri, P., Hilbert, G., Maucourt, M., Deborde, C., Moing, A., and Rolin, D.: Microclimate influence on mineral and metabolic profiles of grape berries, J. Agric. Food Chem., 54, 6765-6775 (2006).

2. Bisson, L. F., Waterhouse, L. A., Ebeler, S. F., Walker, M. A., and Lapsley, J. T.: The present and future of the international wine industry, Nature, 418, 696-699 (2002).

3. Pretorius, I. S. and Høj, P. B.: Grape and wine biotechnology: challenges, opportunities and potential benefits, Aust. J. Grape Wine Res., 11, 83-108 (2005).

4. Cebollero, E., Gonzalez-Ramos, D., Tabera, L., and Gonzalez, R.: Transgenic wine yeast technology comes of age: is it time for transgenic wine? Biotechnol. Lett., 29, 191-200 (2007).

5. Rainieri, S. and Pretorius, I. S.: Selection and improvement of wine yeasts, Ann. Microbiol., 50, 15-31 (2000).

6. Guzzon, R., Widmann, G., Settanni, L., Malacarne, M., Francesca, N., and Larcher, R.: Evolution of yeast populations during different biodynamic winemaking processes, S. Afr. J. Enol. Vitic., 32, 242-250 (2011).

7. Lambrechts, M. G. and Pretorius, I. S.: Yeast and its importance to wine aroma, S. Afr. J. Enol. Vitic., 21, 97-129 (2000).

8. Di Maio, S., Polizzotto, G., Di Gangi, E., Foresta, G., Genna, G., Verzera, A., Scacco, A., Amore, G., and Oliva, D.: Biodiversity of indigenous Saccharomyces populations from old wineries of south-eastern Sicily (Italy): preservation and economic potential, PLoS One, 7, e30428 (2012).

9. Romano, P., Fiore, C., Paraggio, M., Caruso, M., and Capace, A.: Function of yeast species and strains in wine flavor, Int. J. Food Microbiol., 86, 169-180 (2003).

10. Jolly, N. P., Augustyn, O. P. H., and Pretorius, I. S.: The role and use of nonSaccharomyces yeasts in wine production, S. Afr. J. Enol. Vitic., 27, 15-39 (2006).

11. Zott, K., Miot-Sertier, C., Claisse, O., Lonvaud-Funel, A., and MasneufPomarede, I.: Dynamics and diversity of non-Saccharomyces yeasts during the early stages in winemaking, Int. J. Food Microbiol., 125, 197-203 (2008).

12. Subden, R. E.: Current developments in wine yeasts, Crit. Rev. Biotechnol., 5, 49-65 (1987).

13. Valero, E., Schuller, D., Cambon, B., Casal, M., and Dequin, S.: Dissemination and survival of commercial wine yeast in the vineyard: a large-scale, threeyears study, FEMS Yeast Res., 5, 959-969 (2005).

14. Soden, A., Francis, I. L., Oacke, H., and Henschke, P. A.: Effects of co-fermentation with Candida stellata and Saccharomyces cerevisiae on the aroma and composition of Chardonnay wine, Aust. J. Grape Wine Res., 6, 21-30 (2000).

15. Fleet, G. H.: Wine yeasts for the future, FEMS Yeast Res., 8, 979-995 (2008)

16. Renouf, V., Claisse, O., and Lonvaud-Funel, A.: Understanding the microbial ecosystem on the grape berry surface through numeration and identification of yeast and bacteria, Aust. J. Grape Wine Res., 11, 316-327 (2005).

17. Caspritz, G. and Radler, F.: Malolactic Enzyme of Lactobacillus plantarum purification, properties and distribution among bacteria, J. Biol. Chem., 258, 4907-4910 (1983).

18. Esteve-Zarzoso, B., Belloch, C., Uruburu, F., and Querol, A.: Identification of yeasts by RFLP analysis of the 5.8S rRNA gene and the two ribosomal internal transcribed spacers, Int. J. Syst. Bacteriol., 49, 329-337 (1999).

19. Baleiras-Couto, M. M., Reizinho, R. G., and Duarte, F. L.: Partial 265 rDNA restriction analysis as a tool to characterize non-Saccharomyces yeasts present during red wine fermentations, Int. J. Food Microbiol., 102, 49-56 (2005).

20. O’Donnell, K.: Fusarium and its near relatives, pp. 225-233, in: Reynolds, D. R. and Taylor, J. W. (Eds.), The fungal anamorph: mitotic, meiotic and pleomorphic speciation in fungal systematic. CAB International, Wallingford (1993).

21. Legras, J. L. and Karst, F.: Optimisation of interdelta analysis for Saccharomyces cerevisiae strain characterization, FEMS Microbiol. Lett., 221, 249-255 (2003).

22. Vaudano, E. and Garcia-Moruno, E.: Discrimination of Saccharomyces cerevisiae wine strains using microsatellite multiplex PCR and band pattern analysis, Food Microbiol., 25, 56-64 (2008).

23. Stenlid, J., Karlsson, J. O., and Hogberg, N.: Intra-specific genetic variation in Heterobasidium annosum revealed by amplification of minisatellite DNA, Mycol. Res., 98, 57-63 (1994).

24. Zapparoli, G., Torriani, S., and Dellaglio, F.: Differentiation of Lactobacillus sanfranciscensis strains by randomly amplified polymorphic DNA and pulsedfield gel electrophoresis, FEMS Microbiol. Lett., 166, 324-332 (1998).

25. Weisburg, W., Barns, S. M., Pelletier, D. A., and Lane, D. J.: $16 \mathrm{~S}$ ribosomal DNA amplification for phylogenetic study, J. Bacteriol., 173, 697-703 (1991).

26. European Economic Community: Commision regulation (EEC) No. 2676/90 of 17 September 1990 determining Community methods for the analysis of wine, Official J. Eur. Communities, L272, 1-192 (1990). 
27. Di Stefano, R. and Cravero, C. M.: The separation of hydroxycinnamates in wine, Sci. Aliment., 12, 139-144 (1992).

28. Corona, O., Squadrito, M., Borsa, D., and Di Stefano, R.: Behaviour of some compounds with $\lambda \mathrm{MAX}$ at $280 \mathrm{~nm}$ in the determination of total flavonoids of grape skin extracts made from a hydroalcoholic SO2-rich solvent, Ital. J. Food Sci., 22, 347-351 (2010).

29. Di Stefano, R.: Gli alcoli superiori nei vini: influenza della cultivar e dell'annata di produzione, Vignevini, 7, 45-48 (1980).

30. Salgues, M., Cheynier, V., Gunata, Z., and Wylde, R.: Oxidation of grape juice 2-s-glutathionyl caffeoyl tartaric acid by Botrytis cinerea laccase and characterization of a new substance: 2,5-di-s-glutathionyl caffeoyl tartaric acid, J. Food Sci., 51, 1191-1194 (1986).

31. Granchi, L., Guerrini, S., and Vincenzini, M.: I batteri lattici e la fermentazione, pp. 277-288, in: Vincenzini, M., Romano, P., and Farris, G. A. (Eds.), Microbiologia del vino. Casa Editrice Ambrosiana, Milano (2005).

32. Fugelsang, K. C.: Wine Microbiology. Chapman, Hall, New York (1997).

33. Francesca, N., Settanni, L., Sannino, C., Aponte, M., and Moschetti, G.: Ecology and technological capability of lactic acid bacteria isolated during Grillo grape vinification in the Marsala production area, Ann. Microbiol., 61, 79-84 (2011)

34. Fernandez-Espinar, M. T., Esteve-Zarzoso, B., Querol, A., and Barrio, E.: RFLP analysis of the ribosomal transcribed spacers and the 5.8S rRNA gene region of the genus Saccharomyces: a fast method for species identification and the differentiation of flor yeasts, Antonie Van Leeuwenhoek, 78, 87-97 (2000).

35. Tofalo, R., Chaves-López, C., Di Fabio, F., Schirone, M., Felis, G. E., Torriani, S., Paparella, A., and Suzzi, G.: Molecular identification and osmotolerant profile of wine yeasts that ferment a high sugar grape must, Int. J. Food Microbiol., 130, 179-187 (2009).

36. Francesca, N., Canale, D. E., Settanni, L., and Moschetti, G.: Dissemination of winerelated yeasts by migratory birds, Environ. Microbiol. Rep., 4, 105-112 (2012).

37. Sabaté, J., Cano, J., Esteve-Zarzoso, B., and Guillamón, J. M.: Isolation and identification of yeasts associated with vineyard and winery by RFLP analysis of ribosomal genes and mitochondrial DNA, Microbiol. Res., 157, 267-274 (2002).

38. González, S. S., Barrio, E., and Querol, A.: Molecular identification and characterization of wine yeasts isolated from Tenerife (Canary Island, Spain), J. Appl. Microbiol., 102, 1018-1025 (2007).

39. Romancino, D. P., Di Maio, S., Muriella, R., and Oliva, D.: Analysis of nonSaccharomyces yeast populations isolated from grape musts from Sicily (Italy), J. Appl. Microbiol., 105, 2248-2254 (2008).

40. Barata, A., Nobre, A., Correia, P., Malfeito-Ferreira, M., and Loureiro, V.: Growth and 4-ethylphenol production by the yeast Pichia guilliermondii in grape juices, Am. J. Enol. Vitic., 57, 133-138 (2006).

41. Rojo-Bezares, B., Sáenz, Y., Navarro, L., Zarazaga, M., Ruiz-Larrea, F., and Torres, C.: Coculture-inducible bacteriocin activity of Lactobacillus plantarum strain J23 isolated from grape must, Food Microbiol., 24, 482-491 (2007).
42. Ough, C. S., Fong, D., and Amerine, M. A.: Glycerol in wine: determination and some factors affecting, Am. J. Enol. Vitic., 23, 1-5 (1972).

43. Belajova, E. and Suhaj, M.: Compositional profiling of Slovakian wines from distinct production systems by analysis of main saccharides and glycerol, J. Food Nutr. Res., 51, 173-183 (2012).

44. Gardner, N., Rodrigue, N., and Champagne, C. P.: Combined effects of sulfites, temperature, and agitation time on production of glycerol in grape juice by Saccharomyces cerevisiae, Appl. Environ. Microbiol., 2022-2028 (1993).

45. Hernandez-Cortes, G., Cordova- Lopez, J. A., Herrera-Lopez, E. J., MoranMarroquin, G. A., Valle Rodriguez, J. O., and Diaz-Montano, D. M.: Effect of $\mathrm{pH}$, aeration and feeding non-sterilized agave juice in a continuous agave juice fermentation, J. Sci. Food Agric., 90, 1423-1428 (2010).

46. Hinreimer, E., Filipello, F., Webb, A. D., and Berg, H. W.: Evaluation of thresholds and minimum difference concentration for various constituent of wines. III. Ethyl alcohol, glycerol and acidity in aqueous solution, Food Technol., 9, 351-353 (1955).

47. Sipiczki, M., Ciani, M., and Csoma, H.: Taxonomic reclassification of Candida stellata DBVPG 3827, Folia Microbiol., 50, 494-498 (2005).

48. Tofalo, R., Schirone, M., Telera, G. C., Manetta, A. C., Corsetti, A., and Suzzi, G.: Influence of organic viticulture on non-Saccharomyces wine yeast populations, Ann. Microbiol., 61, 57-66 (2011).

49. Hoffert, D.: The action of yeast on lactic acid, Biochem. J., 20, 358-362 (1926).

50. Capucho, I. and San Romao, M. V.: Effect of ethanol and fatty acids on malolactic activity of Leuconostoc oenos, Appl. Microbiol. Biotechnol., 42 391-395 (1994)

51. Alexandrea, H., Costellob, P. J., Remizec, F., Guzzoc, J., and GuillouxBenatiera, M.: Saccharomyces cerevisiae-Oenococcus oeni interactions in wine: current knowledge and perspectives, Int. J. Food Microbiol., 93, 141-154 (2004).

52. Schutz, M. and Radler, F.: The presence of malic enzyme and malo-lactic enzyme in various lactic acid bacteria, Arch. Microbiol., 96, 329-339 (1974).

53. Lopez, I., Lopez, R., Santamaria, P., Torres, C., and Ruiz-Larrea, F.: Performance of malolactic fermentation by inoculation of selected Lactobacillus plantarum and Oenococcus oeni strains isolated from Rioja red wines, Vitis, 47, 123-129 (2008)

54. Beltran, G., Torija, M. J., Novo, M., Ferrer, N., Poblet, M., Guillamon, J. M., Rozes, N., and Mas, A.: Analysis of yeast populations during alcoholic fermentation: a six year follow-up study, Syst. Appl. Microbiol., 25, 287-293 (2002).

55. Ribereau-Gayon, P., Dubordieu, D., Donèche, B., and Lonvaud, A.: La natura chimica, l'origine e le conseguenze dei principali difetti organolettici, pp. 225-235, in: Ribereau-Gayon, P., Dubordieu, D., Donèche, B., and Lonvaud, A. (Eds.), Trattato di enologia, vol. 2. Edagricole, Bologna (2003). 